\title{
FIRE: Forum for International Research in Education
}

\section{Volume 3}

Issue 2 Inclusion not Exclusion: Comparative

Educational Perspectives at the Heart of Sustainable

Article 6

Development in the Gulf States

2016

\section{International Higher Education for Whom? Expatriate Students, Choice-making and International (Im)mobility in the Northern United Arab Emirates}

Lee Rensimer

University of Wisconsin-Madison, rensimer@wisc.edu

Follow this and additional works at: https://preserve.lehigh.edu/fire

Part of the Higher Education Commons, and the International and Comparative Education Commons

\section{Recommended Citation}

Rensimer, L. (2016). International Higher Education for Whom? Expatriate Students, Choice-making and International (Im)mobility in the Northern United Arab Emirates. FIRE: Forum for International Research in Education, 3(2). http://dx.doi.org/10.18275/

fire201603021092 


\title{
International Higher Education for Whom? Expatriate Students, Choice- making and International (Im)mobility in the Northern United Arab Emirates
}

\begin{abstract}
This article identifies a research gap on expatriate students attending international branch campuses in their country of residence, and presents evidence that they are insufficiently distinguished from international students in research on student mobility and choice-making. It finds that the priorities and enrollment choices of expatriates are often understood using the same analytical language as for students who migrate for the purpose of education, particularly through the use of rationalist "push-pull" models and agent-centric frameworks that approach choice and mobility as inherent to all international students. The study suggests that the enrollment choices of expatriates studying at fee-charging international institutions are better understood through research discourses typically applied to non-mobile, domestic students, such as access, affordability and opportunity. Using a mixed-methods research design combining questionnaires and interviews, the author examines the pathways and obstacles experienced by expatriate residents studying at international institutions in the Northern Emirate of Ras Al Khaimah in the United Arab Emirates. It finds that expatriate student choices are often constrained by structural factors that limit their mobility, including costs and family commitments, and are informed by senses of belonging and familiarity in their adoptive country of residence. Findings are contextualized through a discussion of an international education market which capitalizes on immobility and commercializes access to expressions of global citizenship. It concludes with implications for mobility research and calls for greater nuance in discussions on students attending international institutions of higher education.
\end{abstract}

\section{Keywords}

International student mobility, choice-making, student choice, expatriates, international higher education, United Arab Emirates

\section{Cover Page Footnote}

The author would like to thank the students who generously offered their time and candor, the staff at participating institutions for their help and hospitality, and to everyone at the Sheikh Saud bin Saqr Al Qasimi Foundation in Ras Al Khaimah for their unceasing, unrivaled support and encouragement. 
INTERNATIONAL HIGHER EDUCATION FOR WHOM? EXPATRIATE STUDENTS, CHOICE-MAKING AND INTERNATIONAL (IM)MOBILITY IN THE NORTHERN UNITED ARAB EMIRATES

\author{
Lee Rensimer ${ }^{1}$ \\ University of Wisconsin-Madison, USA
}

\title{
Introduction
}

The rise of a global educational export industry has dramatically expanded the higher education choices of students worldwide who, as consumers, are offered an ever-increasing range of international degree programs, price ranges, and mediums of instruction. This trade in commercialized higher education services has changed not only the analytical language used to talk about students vis-à-vis their state of residency but also national discourse, as countries are framed as net exporters and importers of higher education, "home" countries and "host" countries, and study destinations (Kehm \& Teichler, 2007; Naidoo, 2009; Tilak, 2011). Internationalization and international student mobility are two expansive research areas that have enjoyed lively debate, particularly over the past two decades, and both areas are complicated by the simultaneous import of students (e.g., teaching international students at "home" universities) and the export of institutions (e.g., international branch campuses and franchises). The overlapping language of all things international-international students and international institutions in (inter)national spaces - appears to have made the term all but redundant as a useful research analytic in a globalizing era.

The United Arab Emirates (UAE), one of several emerging epicenters or "hubs" of international higher education, is host to the largest number of international degree providers worldwide (Knight, 2011). Unlike other major importers such as Malaysia or China, however, a strong majority of its nearly 150,000 higher education students ${ }^{2}$ are themselves international, reflecting its broader demographic trends, with over $80 \%$ of the population comprised of nonEmirati expatriates ("UAE, Qatar have highest expat ratio in GCC," 2013; Wilkins, 2013). Within higher education, that ratio is further exaggerated through welfare state policies that enable a two-

\footnotetext{
${ }^{1}$ Correspondence: Lee Rensimer, Educational Policy Studies, University of Wisconsin-Madison, 235 Education Building, 1000 Bascom Mall, Madison,WI 53706, USA; Email: rensimer@wisc.edu.

${ }^{2}$ Figure based on a combined sum of 128,279 students at federal and federally accredited institutions, 18,144 in Dubai's free zones, and another 2,000 in Ras Al Khaimah's free zones. Figures on federally accredited institutions are published through the UAE Ministry of Higher Education and Scientific Research Factbook (2014), while free zone figures were provided through correspondence and interviews with free zone staff in 2015.
} 
tiered system, one providing free education for Emirati nationals at the three federal institutions ${ }^{3}$, and the other a private or semi-private (including fee-charging local institutions) market for its diverse expatriate majority. Like secondary schools and healthcare in the UAE, the explosion in private provision since the mid-1990s has led to the growth of a highly commercialized higher education market, which expands student access and choice while keeping talent on-shore (Knight, 2013). Its diverse consortium of international brands serves as a magnet, which simultaneously stems the outward flow of degree-seeking expatriate residents while also attracting non-resident international students from overseas. The consequence is the disruption of the dominant trajectories of international student mobility and the complication of reductive exporter/importer binaries.

This paper argues that the literature on international student mobility and its language of "choice" and "choice-making" does not adequately reflect the nuanced needs of foreign residents generally and the UAE's expatriate students in particular. It finds that discussions around international student choice-making and mobility seldom address the sizable number of students who are de facto international, having not actually crossed borders for the purpose of study and yet are regarded quantitatively and discursively as "international students" in the parlance of most international student mobility studies. As a critique and point of departure from studies that theorize broadly on international student choice-making, this study specifically looks at the experiences of non-Emirati residents studying at international branch campuses or degree franchises in the Northern Emirate of Ras Al Khaimah. In examining their accounts of "choice", mobility, desire, and belongingness, it argues that not all international students are guided by the same rational calculations articulated in push-pull models of student circulation mainstreamed in a popular study by Mazzarol and Soutar (2002). Rather, it finds that such students' choices are constrained by structural limitations on their mobility, and informed by senses of belonging and familiarity in their country of long-term residence. Within this narrowed range of choice, decisions to study in situ are further informed by the practices of a commercial higher education sector that offers an alternative to study in "home" countries (countries of citizenship) and "abroad" (typically Western destinations).

\section{Theoretical Framings}

Research on global higher education, internationalization, and international student mobility has converged and in many ways found new purpose with the soaring developments in global education export/import markets and the entrenchment of market logic in internationalization. On the "abroad" or "overseas" end, the discussion has concentrated on the international branch campus (IBC) phenomenon and the many questions it poses for the future of higher education, while the "home" dimension has primarily focused on international students attending home campuses and institutions' and faculties' abilities to respond. Both are concerned with mobility and the flows or pathways that they shape, and both are strongly influenced by dominant norms around the assumed benefits of being "global".

\section{International Student Mobility and Choice}

With the dominance of market logic that has taken hold, particularly in British and Australian higher education, research on student mobility has taken a decidedly managerialist tack, with numerous studies coming out of the marketing and management fields (Soutar \& Turner,

\footnotetext{
${ }^{3}$ United Arab Emirates University in Al Ain, Zayed University in Dubai and Abu Dhabi, and the Higher Colleges of Technology system, syndicated throughout all seven Emirates.
} 
2002). These works are centered on concepts of student "choice" and "decision-making", framing international students as consumers of foreign educational services in a global market (Maringe \& Woodfield, 2013) and as actors practicing economic agency through a knowable universal rationality (Collins, Sidhu, Lewis, \& Yeoh, 2014). This market logic is in part reflected in the language used to conceptualize choice. Educational consumers are understood through their perceptions and motivations, while countries and institutions leverage their brand image in order to recruit fee-paying customers. The individual and structural context in which these choices operate, framed as "push-pull factors," were mainstreamed in a large multi-country study by Mazzarol and Soutar (2002) that sought to conceptualize international student destination choice as a combination of economic and social factors. Following on this has been a swath of empirical work that refines their original model across various binational pathways (see Wilkins, Balakrishnan, \& Huisman, 2011 for an extensive list). Studies using this framework importantly identify key factors in mobility, including cost, environment, familiarity of destination, geographic proximity, the role of parents, social networks, and access to information used to make determinations.

The key concerns of push-pull studies illuminate the contrast in the dominant discourses used in studies on choice in the international context and those on domestic higher education. The factors identified in push-pull models are not new to higher education in the United States (US), long a commodified good in a market-driven sector (Moore, 1989; Newfield, 2008). Unlike mobility in international contexts, however, domestic higher education research discusses cost in the context of access and affordability, driven by research on inequality and (in)opportunity in the distribution of education. Recent work on intra-national mobility and inopportunity explores access through similar factors of geographic inaccessibility and cost of travel (Hillman, 2016). These studies and their discourses contrast further with research on international student flows, still primarily preoccupied with flows of full fee-paying positional elites or privileged recipients of national scholarships. Set among these actors, notions of affordability and access are thus denormed and subsumed in the internationalization market language of deterrents, "cost factors," "competitive advantage," and so forth. Mainstream international mobility research is again distinguished from the discourses on migration and education, migrants, diaspora, and foreign residency (Raghuram, 2013). What these disjointed discourses draw attention to is the different uses or implications of "mobility": one as the enactment of movement, and the other as the potential for or constraints to movement. The distinction is key for this study as it discusses immobility as a consequence of, and stand-in for, inopportunity.

Also at the core of debates on student choice are questions of rationality and individual agency, often framed without deep reflection on the ways rationality is constructed. More common is work that examines choice as constrained or bound by perceptions and influences within a predetermined structure specific to a particular national group or demographic (Cubillo, Sanchez, \& Cervino, 2006; Hemsley-Brown, 1999; Mazzarol \& Soutar, 2002; Reay, David, \& Ball, 2005). Recent critical scholarship on international student mobility eschews operative notions of rationality in favor of a governmentality analytic linked to post-colonial subject construction and the macro-processes of neoliberal globalization (Koehne, 2006; Raghuram, 2013; Rizvi, 2011; Sidhu, 2006). This approach interrogates the assumptions of individual agency implicit in student choice-making and pivots the focus onto institutions, commercial education industries, and destination countries for their nation-branding exercises. To them, "these calculations are not ... made in a void, but within an imaginary of global conditions and possibilities," with such possibilities being constantly shaped and reshaped by historically-refined flows of ideas and the 
shared assumptions underpinning neoliberal governance (Rizvi, 2011, p. 698). These works call attention to the limits of push-pull models by connecting the choices students make to the broader discursive processes that give breath to those choices, in particular, which destinations are desirable or where is or is not seen as cosmopolitan. Collins et al. (2014) focus on Deleuze's notion of "desire" - to circulate, to become, to escape - and deeply held desires of fulfilment that extend beyond the rational gaze. Such desires are materialized by international students through pursuits of cosmopolitanism, global citizenship, or participation in a perceived global polity (see Fong, 2011, for an empirical illustration of this). The post-structural lens that these works refine importantly allows us to look at student mobility from a position of multiscalarity "as it articulates from the level of the student body, through university, urban, national, regional, and global spaces" (Collins et al., 2014, p. 664), thereby capturing more broadly the complementary and contradictory relationships between actors. Flows of international students are thusly enactments of individual choice as much as they are expressions of globalization and the work of social and political institutions.

\section{Expatriates and the $U A E$}

The link between students and the political work of the state in studies like Collins et al. (2014) is especially relevant to the UAE, where as in Singapore, efforts to capture and re-engineer the public imagination are at work to make spaces like Dubai a desirable destination to live, work, and study. This work calls attention to the contradictions between its different actor-subjects. International students are a complex, highly diverse actor group, and as Raghuram (2013) argues, they are simultaneously workers, family members, and importantly, migrants. Her call to broaden the discourse around international students to include other types of knowledge-seekers allows for richer discussions beyond the relationship between student and university. In this vein, international students are many of the other discursive classifications of non-citizens in the UAE: expatriates, immigrants, foreign residents, and "migrant laborer" or "guest worker," terms which often have the misfortune of being ascribed along lines of race, national origin, and social class (Koutonin, 2015).

The complex identities of expatriates and their relationships to place raise important questions for researchers of globalization, migration, and education. Research on expatriation has long offered interpretive ethnographic accounts of identity, resilience and belongingness, such as Useem's “Third Culture Kids" (1976) and Schaetti's "Global Nomads," (1998) although like much contemporary research, these were proffered with reference to Western expatriates, particularly youth, in non-Western spaces. Of course the pathways of transnational movement and identities of expatriates are in many ways inseparable from colonial imaginaries (Fechter \& Walsh, 2010). The link between discourses on expatriates and particular geographies again raises critical questions on who has rights to belonging and under what conditions, who is entitled to global citizenship, or which spaces get to be cosmopolitan.

Several recent ethnographic works address these problematics of biopolitics in their accounts of the non-Western expatriation experience. Vora's (2008, 2013) work explores belongingness among middle class Indian diaspora in Dubai, finding that state policy is also embodied and re-authored through Indian identity to reimagine the UAE as an extension of the Indian 'homeland'. These informal modes of belonging in the face of strict state controls on permanent residency challenge exclusionary state constructions of citizenship and afford new imaginations of 'home' (Kathiravelu, 2010). Such accounts capture the hybridity, incompleteness, and contradiction that expatriates experience as agents and subjects in a global and national 
governance project. They also point to the ways in which the desires to belong and to stay play an important role in this project, an argument that extends in equal measure to expatriate students.

The literature on expatriation and education is more disparate, as noted, due to the divergent discourses around international students, migration, and educational opportunity. The link between the terminology used and the purpose of migration is often left to the state to define. This problem was incidentally highlighted in the OECD's Education at a Glance report, wherein some participating countries reported their tallies of international students while others counted "foreign students" as a byword for expatriate residents (see OECD, 2012, p. 368). Thus the necessity to cross borders, obtain particular visas, or travel for certain purposes is a popular albeit internationally varied set of criteria for distinguishing international students from their in situ counterparts. In this context the UAE as both a place of residence for multi-generation resident non-citizens and of international students becomes a fertile space for exploring questions around their distinction, like who is counted, who is considered to belong where, and what their international mobility pathways look like.

The UAE's practice of importing its higher education provision from international providers adds a layer of complexity, enabling mobility by proxy; that is, accessing international degrees from home. Despite the wealth of research on IBCs and international degree programs in the UAE, few studies empirically engage with student experiences of choice, access, or student mobility pathways shaped by local access to international institutions. Recent works by Wilkins (2013) and Wilkins et al. (2011) do pioneer research on "choice-making" among Dubai student expatriates, bridging the marketing literatures on choice and the more often anthropological accounts of expatriation. At the same time, by looking at students in private international schools their study reinforces ideas of who is considered an expatriate, and it acknowledges yet stops short of critically engaging with the operative differences between international students and expatriates. While not aiming to theorize expatriate student immobility necessarily, Wilkins (2013) does account for the role of parents, particularly of culturally conservative backgrounds, in constraining choice, as well as the role of IBCs in widening access and opportunity to such students.

\section{This Study}

The paper draws on the findings of a larger study investigating higher education access and opportunity in the northernmost emirate of Ras Al Khaimah (popularly referred to as "RAK"). That study collected data on international degree providers, their students, and commercial and regulatory practices over a six month period between winter 2014 and spring 2015. Research methods included interviews, questionnaires, observations, and document analysis. It found, among other things, a sector in transition with an under-regulated relationship between the competitive market practices of commercial degree providers and a semi-captive studentconsumer base (Rensimer, 2015). It found (im)mobility and affordability to be frequent considerations of students and the commercial providers in Ras Al Khaimah catering particularly to students facing either financial or geographical constraints.

\section{Instruments}

The first instrument applied to this study was a brief questionnaire distributed to international students at four international branch campuses or degree franchises operating in Ras Al Khaimah with the overall participation of 103 students. This instrument yielded descriptive data on student trends across multiple institutions and demographics within the emirate. Its quasiquantitative design was intended to survey broadly and to capture a "snapshot" of the higher 
education landscape, which would then inform directions for deeper inquiry using more qualitative tools. Several dominant national brands and a wide range of international students by origin were captured in the data.

The second instrument was a series of one-on-one interviews with students at one popular international institution, with a subset of those interviews limited to six resident expatriate students. Interviews took place on campus and lasted between forty and sixty minutes each. Both the questionnaires and the interviews covered topics of student choice-making, mobility (interand intra-nationally), access to information, future plans, and their relationship to the UAE.

\section{Participants}

The institutions selected for the study are thought to be appropriately representative of the wider commercial ${ }^{4}$ international higher education market in Ras Al Khaimah. This market includes both IBCs and international degree franchises, a categorical distinction which is often overstated elsewhere (see Altbach, 2012, for example) given that degree franchises and IBCs in the UAE both enter business partnerships with infrastructure and service providers which own and lease the physical campuses to the international degree provider. In Ras Al Khaimah, most of the degree providers are in fact franchises given their local ownership and semi-autonomous management. Two of the institutions participating in this study are among the largest commercial providers in Ras Al Khaimah, with their combined enrollments totaling one-third of market share in the sector. The six expatriate international students participating in interviews were enrolled in the largest international degree provider in the emirate. They originated from three countries all from the South Asia region. Four were male, two were female, and all were between the ages of 18 and 23. To ensure the confidentiality of the student participants quoted below, pseudonyms are used followed by their country of citizenship.

\section{Context}

For a study on expatriate students, mobility and access, Ras Al Khaimah serves as an appropriate research context. It is a spacious, less urbanized emirate and is the farthest from Dubai and Abu Dhabi, although it is well connected by the major arteries running from north to south. These roads enable commuters from as far as Abu Dhabi access to Ras Al Khaimah and vice versa. Its overall population in 2012 was 416,600, or roughly 5\% of the total UAE population; however, an estimated $70 \%$ of its population consists of Emirati nationals, which sits in sharp contrast to the more populous emirates of Abu Dhabi, Dubai, and Sharjah where expatriates greatly outnumber nationals (Oxford Business Group, 2012). Importantly, Ras Al Khaimah has neither the petrocarbon resources of Abu Dhabi nor the global financial services industries of Dubai funding its growth, and as a result the emirate has a considerably smaller public expenditure for the highprofile construction projects and investments that command the global imagination as its larger peers do.

\section{Limitations}

As this study aimed to understand how expatriate students in Ras Al Khaimah complement or challenge popular assumptions of international student mobility and choice, it focuses its

\footnotetext{
${ }^{4}$ The use of "commercial" is used here to distinguish the private, for-profit international degree providers from the American University of Ras Al Khaimah (AURAK), an emirate-owned local university. AURAK enrolled 492 international students in the 2015-16 academic year, or roughly 15\% of international students studying in Ras Al Khaimah. AURAK was not included in this study.
} 
attention on relatively immobile expatriates studying inside the UAE. The themes that emerge from their narratives and the conclusions reached in this study might have differed if the data also captured experiences and pathways of mobile students, including those studying in other emirates and those studying outside the UAE, particularly expatriates who returned to study in their country of citizenship. A research design comparing the experiences and needs of long-term expatriates with recently arriving international students would also broaden the analysis, although such an undertaking was outside of the scope of this particular study.

Regarding the methods used, a larger number of participants in both the questionnaire $(n=103)$ and student interviews $(n=6)$ would strengthen the findings, particularly as all of the interviewees were of South Asian citizenship. Diversifying participants can be a challenge for research design as purpose and duration of residency in the UAE frequently map out onto nationality, class and gender. In Ras Al Khaimah, most of the international students arriving solely for study were of African nationalities while long-term resident expatriates were most often from South Asia.

Finally, sensitive questions that specifically address socioeconomic background and religion were avoided in the questionnaires and interviews. References to both are implied in students' responses to questions on affordability and choice, with consequences made particularly evident where they intersect with gender. Further research might delve deeper into either of these areas to capture how they articulate with enrollment decisions, mobility pathways, and broader life choices.

\section{Findings}

The Emirate of Ras Al Khaimah is host to roughly 3,250 international or expatriate students $^{5}$, just over half of its total 6,200 students. These figures pale in comparison to those of Dubai, Abu Dhabi, and Sharjah, but are in line with the general trend across the UAE of higher enrollments of non-Emiratis than Emiratis, excluding Abu Dhabi. Putting size aside, the data made available on international students by the UAE's Ministry of Higher Education and Scientific Research are critically missing the nuance that this study is aiming to call attention to. The data are labelled as "expatriate students," but included in these figures are both resident expatriates and international students who have migrated specifically for their higher education. Nationality and country of birth are reported, but it is impossible to determine from these data why or when students came to UAE, and whether their emigration to the UAE had anything to do with higher education (see UAE MoHESR, 2014, pp. 41-44). Dubai and Abu Dhabi likely have much higher proportions of international students who explicitly migrated for the purpose of study due to these emirates' relatively greater international cachet and the profile of their international institutions relative to those in Ras Al Khaimah, but the precise relationships cannot be identified without clear data distinguishing international students from expatriates.

Among those students in Ras Al Khaimah responding to the questionnaire employed in this study, only three of the 103 respondents arrived in the UAE at the age of 18 or older with the stated purpose of studying for a degree. Of the remaining respondents in the sample, one-third were born in the UAE and the rest emigrated for purposes of work or joining with family (see Table 1). For those who were born in other countries, the average number of years spent in the UAE at the time of their participation in the study was 6.7 years. With a median sample age of 22, most had spent

\footnotetext{
${ }^{5}$ This figure combines the 1,256 reported in the 2013/14 UAE Higher Education Factbook (UAE MoHESR, 2014) and estimates provided to the researcher by non-reporting free zone institutions or local regulatory authorities of around 2,000 students.
} 
a sizable number of their formative years in the UAE. The nationalities captured in the sample widely reflected the expatriate demographics of the UAE, with two-thirds of the respondents being of South Asian origin (see Table 2).

In the context of mobility, the data appear to cluster around four types of expatriate students based on responses to questions about their study destination choices and alternate institutions they had considered (see Table 3). The first two types were intra-nationally mobile only, or limited in their range of options to institutions in the UAE. The first type showed little to no mobility; they were limited to institutions in Ras Al Khaimah and nearby Northern Emirates. These students were relatively few, but cited costs and proximity to their families and work as most important factors in their determination, or as seen through the concepts used in this study, as impediments to their intra-national mobility. Comments like "Because I live in RAK and can't go outside of RAK" were frequent, while others linked location and mobility to other factors like family priorities or the cost of fees, personal expenses, and transportation to other Emirates. As the Emirates are interconnected with expansive road networks and each institution typically provides private buses, intra-national mobility was not evidently a constraint factor in of itself. However, the constraints of cost or family for these students result from studying elsewhere in the UAE, and so they expressed in their responses being limited to local institutions only.

Table 1: Purpose of arrival to UAE among participants.

\begin{tabular}{lc} 
Purpose of Arrival to UAE & Number of respondents $(n=103)$ \\
\hline Born in UAE & 35 \\
Came with family before age 18 & 28 \\
Work & 35 \\
Study at tertiary level & 3 \\
Other (such as fleeing conflict in home country) & 2 \\
\hline
\end{tabular}

Table 2: Nationality of participant by region.

\begin{tabular}{lc}
\hline Nationality by region & Number of respondents $(n=103)$ \\
\hline South Asia & 70 \\
Middle East and North Africa & 23 \\
Sub-Saharan Africa & 3 \\
East Asia & 4 \\
Did not respond & 3 \\
\hline
\end{tabular}

The second type was more frequent and demonstrated a broader knowledge of higher education institutions around the UAE, typically citing the Dubai-based competitors of the institution they studied at in Ras Al Khaimah. Some of these students articulated their intranational mobility by commenting on their goals rather than the means, as for example, one asserted that "It doesn't matter in RAK or Dubai or anywhere. The quality of education should be good."

The third and fourth types were also internationally mobile. The shape that this mobility took, however, was mostly limited to study in expatriates' country of citizenship. It was also a 
small contingent of the overall sample. Of the 100 expatriate respondents, only nine were considering both other UAE-based institutions and institutions in their country of citizenship, and another seven were considering only institutions in their country of citizenship. Together they comprise less than one-fifth of the total sample of expatriates. Finally, only two responded that it was a choice for them between study in the UAE and a third location: one in the United Kingdom (UK) and one in Canada. Both studied at the same institution in Ras Al Khaimah and cited their combined residency of 36 years there as a factor in choosing to stay.

Table 3: Degrees of intra- and international mobility

\begin{tabular}{llcl}
\hline $\begin{array}{l}\text { Degree of } \\
\text { mobility }\end{array}$ & $\begin{array}{c}\text { Range of choice (based } \\
\text { on other institutions } \\
\text { considered) }\end{array}$ & $\begin{array}{c}\text { Number of } \\
\text { respondents }\end{array}$ & $\begin{array}{c}\text { Key factors affecting choice to } \\
\text { study in Ras Al Khaimah }\end{array}$ \\
\hline $\begin{array}{l}\text { Limited to no } \\
\text { mobility }\end{array}$ & $\begin{array}{l}\text { Must remain with Ras } \\
\text { Al Khaimah or nearby } \\
\text { emirates }\end{array}$ & 39 & Costs, proximity to family \\
Low & $\begin{array}{l}\text { Anywhere within the } \\
\text { UAE }\end{array}$ & 46 & $\begin{array}{l}\text { Proximity to family, quality of } \\
\text { education within UAE }\end{array}$ \\
Low/ & $\begin{array}{l}\text { Between UAE or } \\
\text { country of citizenship }\end{array}$ & 16 & $\begin{array}{l}\text { Costs, uncertainty of future plans or } \\
\text { tenure in UAE, importance of } \\
\text { studying at an institution from } \\
\text { citizenship country }\end{array}$ \\
& & & $\begin{array}{l}\text { Convenience and familiarity with } \\
\text { living in UAE }\end{array}$ \\
\hline
\end{tabular}

While the term "choice" is used here, it needs to be emphasized that it is not unrestricted choice. Where students had any role in the decision at all, structural and sociocultural factors shaped the contours of opportunity and the perceptions of possibility to construct the parameters of "choice". The mobility pathways described above articulate this, wherein the types of institutions students perceive as possible and desirable (and those not stated presumably impossible or undesirable) are highly circumscribed. As the students in this context have little to no international mobility, the language of "push" and "pull" factors is inapt, even though costs, one of the major determinants identified in this study, might map onto "pull" factors in Mazzarol and Soutar's (2002) model. More appropriate is the language of constraints and opportunities for international or intra-national mobility. Doing so resituates the agent-centric language of "choice" in mobility studies to the context of economic migration, low-income families and a biopolitical regime that tightly controls border crossings along national and racial lines. As de facto internationals, expatriate students have already experienced mobility, and while their bi-directional pathways to their country of citizenship usually remain open, other pathways do not necessarily appear ex nihilo or through residency in the UAE alone.

\section{Cost as a Determinant}

The direct and indirect cost of higher education was the largest influence on expatriate students' choices and determinant of mobility. For some of the interview participants, tuition cost was an explicit factor in their personal or family decisions. Affordability was often articulated 
through a comparative lens, with the cost of attending an international institution in Ras Al Khaimah framed against local semi-private institutions (e.g. AURAK, RAK Medical and Health Sciences University), institutions of similar national origin in Dubai, or the nearest equivalent in the students' country of origin. For some, there was no choice or agency:

"Usually the parents send their children back to [their] home country, because here they can't afford [education], it's very tough. Usually the fees of the university [in UAE] are very expensive." (Haneen, Pakistan)

For others, there is choice, albeit limited:

"Okay, let me be honest. The thing is, my parents wanted... in fact, I wanted to go Pakistan for my studies and all because, being honest, I couldn't afford any of the universities and I never knew about [the international institution in Ras $\mathrm{Al}$ Khaimah]. So my friends..., two of them, studied at [the same institution] itself, so they told me there's a campus in Ras Al Khaimah and they do an engineering course and all. I'm like, okay let's have a look at it, so I knew of [competitor institution of same national origin in Dubai] but [it] was too costly for me. It's a good university though, but I came to [the institution in Ras Al Khaimah]... I loved it in fact." (Abdulrahman, Pakistan)

This student had institutions in Dubai and Pakistan in his sights, drawing on language of desire (to study in Pakistan) and of individualism ("I couldn't afford"). However he, like all of the interview participants, was financially supported by his family and bound by collective decisions. When compared to the other interviewees he was likely under the least pressure from family in terms of his institution, location and degree choice. Nevertheless, his selection was partly framed by consideration of the financial cost to his family, noting that his elder brother, also living with the family in Ras Al Khaimah, was not given an opportunity to study and instead took up semi-skilled work to support his family. Others framed responses similarly, contextualizing cost as a factor that weighed against their personal commitment to family:

"Cost was also an issue ... My father was saying that you can go anywhere you want and said it's no problem for me that you can choose any university you want to go anywhere, wherever you want to go, but as a son I also have to think like, okay he is my father, he is offering me this time, so it's fine but anything will happen in future, and I need to save as much as I can and get whatever I can, like ... in less money..." (Hamza, Pakistan)

These excerpts highlight the contextual and social nature of affordability, given young students' dependency on their families. They differ somewhat from the priorities expressed by more privileged expatriates in the UAE (Wilkins, 2013) and complement the findings of Li and Bray's (2007) study which argued that the parameters of choice and of affordability are simultaneously shaped in and by dynamic social contexts.

One notable observation is that the students, despite studying at an institution originating from a Western country, did not talk about the cost of studying at the same institution in its home country. It may go without saying that if cost was a decisive factor within the UAE, the cost of 
study in the US or UK would as well. The fees at most branch campuses in the UAE are generally lower than they would be in their home countries, and these rates are further shaped through competitive marketing, including early registration discounts and "scholarships" for new students with high secondary school scores. However, it also underscores elements of preference, including the desire to be near or with family, attend an institution that simultaneously feels international yet familiar or recognizable, and have in place social networks to draw upon. These too might be usefully understood as social costs that bear on the individual student and the family, and thus weigh on the scope of possibilities.

\section{Family}

More than social networks generally, the draw of family in shaping opportunity or curtailing mobility featured prominently in students' responses. Students again talked about the benefits of proximity for cost-saving, security and general ease of living. This was articulated through the perspective of their parents as an obligation to remain together, maintain certain social practices, or provide material support to the family.

In many of the cases, choices were minimal to absent entirely. In a more extreme example, one student stated, "My parents took me from the Philippines so they may have the chance to take care of me while I'm still immature. It's not because I want to study here [in Ras Al Khaimah]." As for his choice of institution, he continues, "[It] was my parents' choice. They just enrolled me here without me knowing it."

More common, however, was the sense of obligation, such as in the issue of cost, and the appeal of keeping the family together. One interviewee considering returning to India to study was dissuaded by his father, who placed greater importance on keeping the family together over known benefits of universities overseas:

"Even when my dad was telling about the Indian universities, because they have ... good reputation and this and that, because my dad is also here he told if I'm here, you also study here. So he also got convinced, like 'If I'm staying in Ras al Khaimah, you also [stay] in Ras al Khaimah so you will be with us. If you go again to India then we will meet in six months.' So he was like 'Okay, you study here.'” (Harjit, India)

The selection of degree subject was similarly influenced by family considerations and an obligation to study a program acceptable to parents. As the overwhelming majority of international higher education degree programs in the UAE are vocational in nature - engineering and business administration especially - students' enrollment at an international institution often assured a degree that spelt a career pathway in line with parents' expectations. When one male student was asked whether he was under any pressure from his parents, he quipped, "Yeah, actually being a Pakistani kid you always have three options: either you can get into medical, engineering, or law. That's it." Asked if this was his reason for studying engineering, he followed, "They never forced me to, but I think if they want me to go for engineering or something I'll go for it, no problem."

The family dynamic, however, is intersected by gender and the attendant expectations placed on gendered roles. Female interviewees did not talk about explicit or implicit expectations to support the family as males did, their language instead suggesting the role of familial paternalism in providing them "protection" from the necessity of studying overseas. In these cases their physical mobility and study choices were circumscribed as a consequence of their gender. 
For one Pakistani interviewee, her parents prohibited both studying in her country of citizenship and in the UK. Their decision to bar her study in Pakistan was articulated on grounds of her personal safety, but the UK was also ruled out even though her brother had studied there and her father traveled there frequently for his business. When asked about choices in light of intranational mobility, she emphasized the distinction between commuting alone on a daily basis to a campus anywhere within the UAE to "going outside" by studying abroad, where parents could not regularly look after them. Another female Pakistani interviewee similarly noted that she was free to study anywhere in the UAE for her next degree provided that her younger brother attended the same institution and moved with her.

Both female participants talked about the high costs of higher education, and both had originally intended to study medicine with their parents' encouragement. Again, affordability is contextualized by the dynamics of gender and family obligation. With the exorbitant costs of medical programs in the UAE and the only alternative being returning to Pakistan to study, both resorted to studying other subjects in order to comply with the needs or expectations of their families. Here, as in other examples, family both enables and constrains choice, calling attention to the ways that choice and mobility are inextricably embedded in their social or collective contexts.

The role of family on these expatriate students' choices and opportunities appears to cut against the studies on international students, which find that the reputations of institutions generally have a greater influence on choice than that of parents (Mazzarol \& Soutar, 2002; Pimpa, 2005). It does cohere, however, with Raghuram's (2013) position that migrant students have multiple identities and are guided by their simultaneous roles as family members and as individuals seeking knowledge and positional gains.

\section{Discussion}

The study's findings draw together shared and divergent experiences of immobility among expatriate students, speaking to the ways in which expatriates - simultaneously subjects and agents of globalization - are localized. The constraints to their mobility tease out some of the broader structures and regimentations that keep people in place while also identifying pathways for possibility. The following section places some of these emergent findings into broader dialogue with themes explored in the literature on mobility and expatriation.

\section{Banal Cosmopolitanism and Strategic Mobility}

Studies on international students often interrogate the ways students conceptualize global citizenship and the strategies they pursue to accumulate its materialities (Fong, 2011; Matthews \& Sidhu, 2005). What the studies find are representative experiences of "becoming global" "out there," particularly in Western geographies, through intensive exposure to banal cosmopolitanisms, particular forms of cultural literacy, and in some cases the attainment of foreign residency. Nonetheless, mobility is framed as a predetermined property of self, often to elite families, and is actualized through migration and the embodiment of cosmopolitanism.

What the findings of this study suggest are ways that mobility is understood not as a means to something else but as an end goal in and of itself. Responses appear to indicate that mobility is understood as something that can be achieved through study at an international institution. For most it was not a literal misunderstanding that an international degree would be a credit towards foreign visa eligibility, although this perception too surfaced from time to time during the study. 
Rather, it is evinced through articulations of the perceived value of an international, particularly Western degree and the attendant experiences of cosmopolitanism, banal or otherwise, on campus.

According to a separate set of interviews with international institution recruiters and staff, a common concern among their potential students is whether or not the degree identifies where it was earned, for example at "New York University Abu Dhabi". The concern stems from the potential misperception, particularly by employers, that the degree is not equivalent to a degree issued from the home campus. Here, the fear of localizing a "global" product, one that carries global import, is indicative of some of the same mobility and global citizenship discourses that the expatriate students denoted in their interviews. Accordingly, students talked about the Western degree they would earn in contexts of potential mobility and expanding opportunity. In contrast, they linked degrees from either the UAE or their country of citizenship to narrowed employment potential and an ossification of their current mobility. In these articulations, degrees from a UAE institution were discursively framed as "local," as were those from their citizenship countries. Despite potentially real material consequences that they all were aware of, it was also shaped in contrast with what was normatively desired through their Western degree: the pursuit of a global identification and cosmopolitan signifier. To interview participants and their families, a "global" degree was considered a more strategic choice than a "local" degree, even where they expressed aspirations to stay and work in the UAE. When asked about Shaheed Zulfikar Ali Bhutto Institute of Science and Technology (SZABIST), a Pakistani branch campus in Dubai, one responded:

"SZABIST... My father's like if you are living here, why are you choosing a degree from Pakistan? Why don't you go out there and have a degree from Pakistan. If you're living here just choose a degree from the outside because in the future we don't know where we will go. What if you go to the British or the America [sic], at least you have their degree also. You can work from out of the world, means all over the world you can work. But for a Pakistani degree, I don't think so, I don't think they will accept [it]. I don't think the others, the UK or American, they will accept our degree. My father is like, don't choose Pakistan degree. If you are living here, if you're studying here, then choose some other degrees from American or British [schools]. Don't choose a Pakistani degree. I think the UK and American degree has more value than the Pakistan degree." (Fawziah, Pakistan)

These comments also speak to an assumed deterritorialization of knowledge at the tertiary level. According to her father, Pakistani secondary school is appropriate in order to learn national culture, language, and particular socialization processes, but higher education is divorced from these. Seen rather as instrumental job training and denationalized technical knowledge, her father encouraged the pursuit of a Western higher education to capitalize on its relative prestige and the global mobility it was perceived to enable.

Whether or not the difference between degree origins has differing material outcomes is not important here. Relevant to this study is the perception that "global" degrees accord both mobility potential and foundations for global citizenship, a sentiment expressed by many interviewees. Students frequently linked these discussions of degree value to future plans, which in most cases involved attaining a higher degree in an Anglophone country. Australia, New Zealand and Canada were more popular future destinations due to perceptions of these countries having less cumbersome immigration procedures and greater opportunities for employment. Notably, and in alignment with Fong (2011) and others, these imaginary trajectories were not 
permanent or unidirectional, but rather a stage that enabled employment opportunity, experience, and a stable future. These were not articulations of self-transformation, but of strategic mobilities — ones that were achieved in part through attainment of a "globally-recognized" degree. This comes in sharp contrast to the mobilities of elites, typified in studies of Gulf nationals or Chinese citizens, where mobility is preordained.

\section{Problematics of "home"}

Another discussion that the findings speak to are the oft-mentioned notions of "home," and with it, senses of belonging and desires to remain or return. These are important to the discursive construction of mobility, particularly in this study regarding the binary language of "home" versus "abroad" and in the material ways that "home" serves as a resource and eventual destination for expatriate students. Interviewees' articulations of their mobility strategies and intended destinations were referenced with notions that "home" was where family was, where they were most familiar, and where they would eventually return. In most cases "home" was resolutely the UAE, and for others a close second "home," despite the impermanence and sometimes tenuous nature of their residency. These sentiments are contrasted with often phlegmatic descriptions of their country of citizenship as either a place of little familiarity, fewer opportunities, or in some cases instability. For one student his home was articulated as a place of return both physically and sentimentally:

"Because I've spent my childhood over there [in Sharjah], it's where I came to my mind when I was a kid, I opened my eyes in Sharjah ... I'll [always] think about Sharjah. I've never been to Afghanistan. I've been to Pakistan, but I was just one year old so I don't remember anything from Pakistan. So whenever I look back, I have all my memories in Sharjah, in [the] UAE." (Faisal, Afghanistan)

When this was asked in the context of his plans to work and study in Australia or New Zealand, he indicated that return was both inevitable because his family was settled in the UAE and desirable because of its familiarity and cultural resonance as a Muslim country.

However the fondness expressed in responses was often counterweighted with the complex and at times challenging realities of UAE residency. Expatriates in the UAE describe their relationship with their adopted home in conflicted ways, simultaneously permanent and contingent upon conditions of their sponsorship. The lack of opportunity for permanent residence in the UAE was explicitly stated as an issue for two interviewees, and for others, topics of employment, family, future travel, and migration destinations all hinted at the same, with references to home and belongingness coupled with insecurity or a constant awareness of their difference. This difference was articulated even when unintentional:

"Home is where you live, where you know people, where you feel comfortable and all. So yeah, [the] UAE is my home... my home country, this is my home. [pause] It's a bit tricky [he laughs]. Everyone would say that this is my home, this is my home. Because they love [the] UAE, it's given so much to us. The UAE has given so much to the expatriates and all, so yeah why not? It's home for us." (Hamzah, Pakistan) 
The complexities of national identity and expatriate tenure in the UAE are explored in great length elsewhere (Vora, 2008, 2013). However, these complexities are especially germane in the context of international student mobility, where national identity intersects with the politics of migration as well as various discourses of desire for global citizenship and the desire of becoming. There is an argument to be made that these desires are tacitly aroused through the messaging of international institutions in the UAE as they position themselves as doorways to the "global," an argument examined at length by Sidhu (2006) in education-exporting countries. Fully understanding the structural impossibilities of permanent residence in the UAE, students' expression of their desires to seek out secure tenure in Western countries is articulated, objectified, and even commodified through the pursuit of an international degree at an IBC or international franchise.

The allure of the potential and the desire to become global, mobile, and complete may well extend to all international students, and where this intersects with on the one hand commercial higher education markets and on the other, governmental technologies, it may apply to all manners of student mobilities, pipelines, or recruitment. But what makes expatriates unique in this context is their complex spatialities of "home" and the experiences of displacement or vulnerability that attend to them. Unlike international students who circulate and return with their accumulation of various capitals, expatriates must continue to negotiate the challenges of non-citizenship after completing their studies. Effectively attending an international institution without ever leaving "home" comes with its advantages, not least the familiarity of place and the resources that come with established social networks. What is problematic is the simultaneous allure of easy access to the "global" - its knowledge, its attendant experiences — without being given the means to embody the mobility that it represents.

\section{Conclusion}

Literature on both international higher education and the expansion of opportunity in the UAE has covered in much detail the strongly international origins and character of its institutions and students. It has not, however, come to terms with the nuances among its non-Emirati students and seldom acknowledges the overwhelmingly expatriate nature of its international students. This is likely a sore spot for UAE policymakers, as the rhetoric, branding and viability of its vision as a higher education hub is imagined through in-bound student mobility and migration specifically for the consumption of education services. To date this has not been achieved to any great effect, but has been a commercial success among its expatriate population.

The distinction matters for institutions as well, of course, as different students necessarily differ in needs. Thus the resources that are committed to expatriates, including student aid, foundational remediation, transportation, and any number of issues relating to families, are different to those of recently arriving international students, who often arrive alone and for whom affordability is experienced differently. Looked at another way, these two bodies of students have different resources for persevering and overcoming hardship, and from an institutional planning perspective, demand different accommodations.

The experiences of international mobility discussed in this study likely speak to those of expatriate students elsewhere in the Gulf region. More important than its generalizability, however, is its call for nuanced approaches to research on expatriate and international students and recognition of their differing constraints, needs, resources, and aspirations. Future research may wish to comparatively examine the experiences of expatriates and recently arriving international students, or expatriates who repatriate for study purposes. Another approach might look beyond 
the commercial international higher education market to include those international students that attend local, private institutions or in rare cases, the federal Emirati universities. There is still vast opportunity for critical research in this area and the policy work to follow.

\section{References}

Altbach, P. G. (2012). Franchising -- The McDonaldization of Higher Education. International Higher Education, 66(Winter), 7-8.

Collins, F. L., Sidhu, R., Lewis, N., \& Yeoh, B. S. a. (2014). Mobility and desire: international students and Asian regionalism in aspirational Singapore. Discourse: Studies in the Cultural Politics of Education, (January 2015), 1-16.

Cubillo, J. M., Sanchez, J., \& Cervino, J. (2006). International students' decision-making process. International Journal of Educational Management, 20(2), 101-115.

Fechter, A.-M., \& Walsh, K. (2010). Examining "Expatriate" Continuities: Postcolonial Approaches to Mobile Professionals. Journal of Ethnic and Migration Studies, 36(8), 11971210.

Fong, V. (2011). Paradise Redefined: Transnational Chinese Students and the Quest for Flexible Citizenship in the Developed World. Stanford, CA: Stanford University Press.

Hemsley-Brown, J. (1999). College choice: perceptions and priorities. Educational Management and Administration, 27(10), 85-98.

Hillman, N. W. (2016). Geography of College Opportunity: The Case of Education Deserts. American Educational Research Journal, 53(4), 987-1021.

Kathiravelu, L. (2010). Dubai as Metaphor: Local readings of the Global City. Refereed conference proceedings of the Australian Sociological Association Conference, Macquarie University, Sydney, Australia, 6-9 Dec.

Kehm, B. M., \& Teichler, U. (2007). Research on Internationalisation in Higher Education. Journal of Studies in International Education, 11(3-4), 260-273.

Knight, J. (2011). Education Hubs: A Fad, a Brand, an Innovation? Journal of Studies in International Education, 15(3), 221-240.

Knight, J. (2013). Crossborder Education in the Gulf Countries: changes and challenges. In G. Donn \& Y. Al-Manthri (Eds.), Education in the Broader Middle East: borrowing a baroque arsenal (pp. 171-201). Oxford, UK: Symposium Books.

Koehne, N. (2006). (Be)Coming, (Be)Longing: Ways in which international students talk about themselves. Discourse: Studies in the Cultural Politics of Education, 27(2), 241-257.

Koutonin, M. R. (2015). Why are white people expats when the rest of us are immigrants? The Guardian. Retrieved on 10 Oct. 2015 from http://www.theguardian.com/globaldevelopment-professionals-network/2015/mar/13/white-people-expats-immigrantsmigration.

Li, M., \& Bray, M. (2007). Cross-border flows of students for higher education: Push-pull factors and motivations of mainland Chinese students in Hong Kong and Macau. Higher Education, 53(6), 791-818.

Maringe, F., \& Woodfield, S. (2013). Contemporary issues on the internationalisation of higher education: critical and comparative perspectives. Compare: A Journal of Comparative and International Education, 43(February 2015), 1-8.

Matthews, J., \& Sidhu, R. (2005). Desperately seeking the global subject: international education, citizenship and cosmopolitanism. Globalisation, Societies and Education, 3(1), 49-66. 
Mazzarol, T., \& Soutar, G. N. (2002). "Push-pull” factors influencing international student destination choice. International Journal of Educational Management, 16(2), 82-90.

Moore, P. G. (1989). Marketing Higher Education. Higher Education Quarterly, 43(2), 108-124.

Naidoo, V. (2009). Transnational Higher Education: A Stock Take of Current Activity. Journal of Studies in International Education, 13(3), 310-330.

Newfield, C. (2008). Unmaking the Public University: The Forty-Year Assault on the Middle Class. Cambridge, MA: Harvard University Press.

OECD. (2012). Education at a Glance 2012: OECD Indicators. Paris: OECD Publishing. Retrieved from http://dx.doi.org/10.1787/eag-2012-en

Oxford Business Group. (2012). The Report - Ras Al Khaimah 2012. Oxford, UK: Oxford Business Group.

Pimpa, N. (2005). Marketing Australian Universities to Thai Students. Journal of Studies in International Education, 9(2), 137-146.

Raghuram, P. (2013). Theorising the Spaces of Student Migration. Population, Space and Place, 19(2), 138-154.

Reay, D., David, M. E., \& Ball, S. J. (2005). Degrees of Choice: Class, Race, Gender and Higher Education. Stoke on Trent, UK: Trentham Books.

Rensimer, L. (2015). International \& Commercial Higher Education in Ras Al Khaimah: Policies, Problem Areas, and Promise. (Policy Paper 14). Sheikh Saud bin Saqr Al Qasimi Foundation for Policy Research: Ras Al Khaimah, UAE.

Rizvi, F. (2011). Theorizing student mobility in an era of globalization. Teachers and Teaching: Theory and Practice, 17(6), 693-701.

Schaetti, B. F. (1998). What is a global nomad. International Schools Journal, 1(1), 13.

Sidhu, R. (2006). Universities and Globalization: To Market, To Market. London: Routledge.

Soutar, G. N., \& Turner, J. P. (2002). Students' preferences for university: a conjoint analysis. International Journal of Educational Management, 16(1), 40-45.

Tilak, J. B. G. (2011). Trade in higher education: The role of the General Agreement on Trade in Services (GATS). Paris: UNESCO: IIEP.

UAE MoHESR. (2014). The UAE Higher Education Factbook 2013/2014. Abu Dhabi: United Arab Emirates Ministry of Higher Education and Scientific Research.

UAE, Qatar have highest expat ratio in GCC. (2013, September 11). Emirates 24/7 News. Retrieved 14 Oct. 2015, from http://www.emirates247.com/news/emirates/uae-qatar-havehighest-expat-ratio-in-gcc-2013-09-11-1.520659

Useem, R. H., \& Downie, R. D. (1976). Third-Culture Kids. Today's Education, 65(3), 103-105.

Vora, N. (2008). Participatory Exclusion: The Emirati State, Forms of Belonging, and Dubai's Indian Middle Class (Doctoral dissertation). Retrieved from ProQuest Dissertations and Theses. (Accession Order No. 3321585).

Vora, N. (2013). Impossible Citizens: Dubai's Indian Diaspora. Durham, NC, USA: Duke University Press.

Wilkins, S. (2013). "Home" or away? The higher education choices of expatriate children in the United Arab Emirates. Journal of Research in International Education, 12(1), 33-48.

Wilkins, S., Balakrishnan, M. S., \& Huisman, J. (2011). Student Choice in Higher Education: Motivations for Choosing to Study at an International Branch Campus. Journal of Studies in International Education, 16(5), 413-433.

\section{About the Author}


Lee Rensimer is a doctoral researcher of educational policy studies at the University of Wisconsin-Madison. His research focuses on global and transnational higher education, international student mobility, and educational policy-making in the Arabian Gulf. His dissertation examines the commercial export of British higher education, national branding campaigns, marketing practices, and their governmental effect on student-consumers in the United Arab Emirates. Lee earned his master's degree in international development from the University of Manchester (UK) and bachelor's in anthropology from Pennsylvania State University (USA). He has lived, worked, studied and taught in many locations, and for this reason has deep appreciation for the complex (inter)national identities and place-making practices of the students and staff who inform his research. 